\title{
IMPORTANCE OF SEX EDUCATION SINCE EARLY AGE FOR PREVENTING SEXUAL HARASSMENT
}

\author{
Christofora Megawati Tirtawinata \\ Character Building Development Center, Bina Nusantara University \\ Jl. Kemanggisan Ilir III No. 45. Kemanggisan, Palmerah, Jakarta Barat, 11480 \\ ch.megawati_t@binus.ac.id
}

\begin{abstract}
Lack of sex education in children could cause the violence or sexual abuse done by adults. Parents should give the lesson about early sex education to the children so that they had the right knowledge about it and knew how to treat and look after it. The method in this research was a discourse analysis of the literature in which the readings were taken in context with the research topic. Besides that, it included the observations and everyday practical experience in social life. This article described the notion of sex education, the impact of sexual harassment, the importance of sex education for children, and who would be responsible for sex education for the children. The research finds that through the moral education and faith to God, the children are expected to get protection from sexual abuse, so the nation's children as successor generation get mentally active.
\end{abstract}

Keywords: sex education, sexual abuse, early-age children, parents

\section{INTRODUCTION}

Lately, Indonesia is not only shaken apart by natural disasters, such as volcanic eruptions and floods, but also hit by cases of sexual abuse of the children. It started from the disclosure of sexual harassment case at the Jakarta International School (JIS) at the mid of April 2014 that shocked the society. Sexual abuse occurred in JIS (Jakarta International School), one of the oldest international schools in Indonesia, has the most stringent security at every entrance. Also, the more surprising news is the culprits of this crime are the janitors or cleaning service who work in this school, two men and one woman. Further FBI (Federal Bureau of Investigation) reveals that William James Vahey (64 years old) from South Carolina, who allegedly had been raped 90 children was a teacher in JIS at the 1990s to early 2000s (Abdullah, 2014).

Another case of sexual abuse of children happened in SDN 4 Samarinda. It reveals that the culprit of this crime is 50 years old gym teacher. (Yus, 2014). While police in Sukabumi arrests a man named Andri Sobari alias Emon (24 years old) on Thursday, May 1st, 2014. Emon arrested because of the reported from the resident that his/her child is sexually abused by at the bathing site of Citamiang, Sukabumi. To the police, Emon claims that he had already molested dozens of boys in age 6 six years old to 13 years old. It reported that there were 47 victims until Friday, May 2nd, 2014. Hari said there were possibilities that the victims will increase. It indicates that there are more than 100 victims in this case. According to Hari, sex abuse action is done three times in one week. Whereas according to Emon, he has done this action during the past year (Riz, 2014).

Setiawan (2014) reported cases that have occurred in many schools in the capital city: Jakarta. On February 9th, 2013, a student at SMA Negeri 22 West Jakarta said has been sexually abused by the vice-principal named Taufan. The court sentenced him to four years prison and a fine of IDR 60 
million to Taufan. On October 14th, 2013, parents of the student in SMP Negeri 4 Central Jakarta reported that their child is to be a victim of sexual abuse by his/her schoolmates. Harassment scene is filmed with a mobile phone and circulated among students. The case is settled closed that involves the Department of Education and student's parents. On October 29th, 2013, a sixth-grade student at elementary school claimed that being abused by his teacher. The boy was frightened and did not dare to go to school because the teacher threatened. The case closed because police could not find evidence fact.

Tanjung (2014) also reported cases of sexual abuse of minors in Riau. This time, the victim is 16 years old female. The culprit is S (45 years old), a resident who works in Kampar Pekanbaru. Head of Public Information Police Headquarters, Senior Commissioner, Agus Rianto told reporters those cases of wanton violence against minors rampant. After airings incident cases of sexual abuse against Kindergarten (TK) students at Jakarta International School (JIS), similar cases pop up in almost all police in the country. Agus said that according to the data received, it happens all across the country. The reported cases of sexual violence against minors are in 31 police station. However, based on the data received, not all police are on the report. Agus deplored that the sexual abuse of children under the common rife. The culprit classified as teenagers to adult. Agus detailing there is at least 493 case reported to the Public Relations Police Headquarters about this case. The number of suspects recorded as many as 338 people. While the victims children because sexual violence are about 450 peoples.

Cases of sexual abuse of minors have long happened. This case does not only occur in Indonesia but also in other countries around the world. Jane Flanagan (2011) records more than 67,000 cases of rape and sexual abuse against children were reported at 2000 in South Africa while there are 37,500 cases at 1998. Child advocacy groups believe that the number of incidents does not report are ten times the number of cases reported. The largest increasing sexual abuse occurs in children who are at age seven years old.

From some cases that described above as the victims are children both girls and boys, while the abuser is a man who has status as a teacher. Another incident also takes place at school, but the culprit is not a teacher. All of this time, people assume that a school is a safe place for children to study, but in contrary to what happened. The culprit, in this case, is someone who unexpected to do this. There is the possibility that the culprit had ever suffered sexual harassment when they were young or they do it to get power. The aim of this article is to equip the victims of this case to avoid sex harassment.

Based on Habib Asyhad (2014) between ten schools in England only four schools are admitted to study and discuss sex education. Besides that, the survey conducted by Sex Education Forum involving 890 students in 14-25 years old, most of them never discuss sex education in the classroom. Besides, most adults especially parents are reluctant or find it taboo to talk about it to their children. It shows how the right sex education possessed by children that can lead to violence or sexual abuse to the children.

To protect children from violence or sexual abuse like these cases, then the children should be given briefing adequate knowledge about sex at an early age. Now it is time to provide children with an adequate sex education. The question is how to deliver sex education, when it is appropriate to provide sex education to children, and can sex education be guaranteed to avoid sex harassment to children? To answer these questions will be described: (1) What does sex education mean? (2) What is the urgency to give sex education to the children at an early age? (3) Who should teach the children about sex education? (4) What is the danger of ignorance and harassment? This article will discuss these questions and the benefits of early sex education as well as the strategy. With early sex education, it expects that there are no more children to be the victims. 


\section{METHODS}

The method in this article is a discourse analysis of the literature in which the readings were taken in context with the research topic. Besides that, it includes the observations and everyday practical experience in social life.

\section{RESULTS AND DISCUSSIONS}

Before discussion about what is sex education, it will discuss some understanding of education according to some experts scientists first. According to Godfrey Thomson (as cited in Midfilder, 2012), education is the environmental influences on individuals to make the right changes in the habits of behavior, thoughts, and feelings. Then, according to M.J. Langeveld (as cited in Miftakhul Ulum, 2014), education is every interaction that occurs between adults and children is a field or a state where the education takes place. Soemanto (2006) said that education is a learning process that produces experiences that provide personal well-being, both physically and mentally. Dedi Supriadi (2001) said that education is one of the functions that have to do with the best families and communities in an integrated manner with the various institutions that are held with the purpose to develop the educational role. While Carter V. Good (as cited in Darmadi, 1977) conceptualized education as the process of skills development in the form of prevailing attitudes and behavior in society. Social process in which a person is affected by something that guided environment (especially in schools) so that he/she can achieve social skills and develop his/her personalities. The understanding of education according to these experts above can be concluded that education is a conscious effort by adults to individuals including children, with the aim that people acquire social skills that are required in the development of personality. So that it is accordance with the expectations of society, and then that individuals reach inner and outer happiness.

While the meaning of sex itself, by J.S. Tukan in (as cited in Suraji, 2008) is an effect (consequences) of their sex. Sex in this sense includes behavioral differences, differences in attributes, different roles and jobs and the relationship between the sexes male and female. Mugi (as cited in Suraji, 2008) defines sex as a source of stimulus for both inside and outside that influence the behavior of lust, which is natural. Based on these definitions, the meaning of sex includes the genitals, limbs, and traits human other distinguishing male and female, glands and hormones in the body that affect the operation of the organs, the process of fertilization, pregnancy and birth.

According to A. Nasih Ulwan in (as cited in Suraji, 2008), sex education is the effort of teaching awareness and information about sex issues that provides to the children, so that he/she understands the problems relating to sex, instinct, and marriage. It assumed that if the children grow up, they able to comprehend the elements or matters that is permitted and forbidden even able to apply the Islamic behavior as morality, customs, and do not follow the desires and hedonistic ways. According to J. L. Ch. Abineno (as cited in Tarigan, 2015), sex education is education provided to the children about sex knowledge and how to use sex in their life. Meanwhile, according to Syamsudin (as cited in Tarigan, 2015), sex education is an attempt to lead a person to be able to understand thoroughly about the meaning and function of his sex life, so it can use them well throughout their lives. According to Calderon in (as cited in Suraji, 2008), sex education is a lesson to strengthen family life, to foster self-understanding and respect for themselves, to develop the abilities to socialize with people in a healthy manner, and to build the sexual and social responsibility.

The purpose of sex education as said by Professor Gawshi (Madani, 2003) is to provide the right knowledge to the children in preparation to adapt better to the sexual attitudes in the future life. 
Besides that, sex education gives provision of knowledge that causes the children receive tendency of logical true of the problems of sexual and reproductive. In connection with sex education that is important to give it early, it is a conscious effort that is given by adults to children since the young age, with the material provided is knowledge about sexual organs, maintains the right attitude, and treats it. Sex education is an effort to transfer knowledge and value of the human genetic and physical function, especially in respect of the genders of male and female. Sex education is also a teaching effort, awareness, and information about sexual issues to keep the children from the habit of illicit sex, including protected them from sexual harassment.

Sexual abuse of children includes the use of children to fulfill sexual satisfaction of adults, ranging from touch on the sex organs, intercourse, and sodomy. Sodomy also known as anal sex, it is the insertion of the penis into the couple's anus with or without force. In general, the definition of sexual harassment is any action or behavior or gestures the undesirable sexual in the form of verbal (word) or written, nonverbal, physical, and visual sexual interest that are causing outrage feelings of humiliation, embarrassment, discomfort, and unsafe for others. Verbal sexual harassment includes teaching, joking that smelled of sex, invitations of undesirable dating. While non-verbal sexual harassment includes the movements of unwanted sex, showing off genitals, the facial expression that shows the flirtation. And physical, sexual harassment includes rape, touch someone else's body. Children of all ages and genders can be the victims of this case, but most of them are girls that are committed by men. Harassment is usually carried out by people known to the victim, and it can happen to anyone in the community.

Parents must be aware the changes that happen to the children who get violated. The changes include the local changes and the changes of victims' behavior. The local changes can be seen in sex organs like trauma, infection, pain, secretions or bleeding. The changes of victims' behavior like morbid fear, anorexia or nausea, self-harm and sexual behavior that is not appropriate for their age and the environment. Sexual abuse of children gives the harmful impact on them. The damage can affect both short and long term, including psychopathology (mental pressure / abnormal). The impact of psychological, emotional, physical and social of this include depression, post-traumatic stress disorder, bad and low self-esteem, personal identity and anxiety disorders, eating disorders. Psychological disorders are widespread somatization, nerve pain, chronic pain, changes in sexual behavior, the problem of school and learning. Other behavioral problems including drug abuse, self-injurious behavior, animal cruelty, crime and suicide as adults. Long-term negative effects on the mental development of the victims of repeated treatment can give effects until they are growing up. The study said there are cause and result of the sexual abuse of childhood with adult psychopathology cases, including suicide, anti-social behavior.

The development of science and technology has made the world more accessible. Everything becomes transparent and available. Information and sexual experiences can be obtained freely without the filter. Children from an early age are familiar with the technology, and it makes them will easily access porn sites that are harmful to mental and spiritual development. Sexual harassment also has spread in almost all states and cities that make parents worry about the safety of their children. Sexual crimes also have spread in almost all countries and towns, it makes parents worry about the safety of their children. Rahmatullah Rasyid (2013) reported during the first seven months of 2013 occurs sexual offenses in South Korea every 25 minutes. The number reached 22034 sexual offenses increased from previous years, namely 13634 cases in 2007, 15094 cases in 2008, 16156 cases in 2009, and 19939 cases in 2010. After a series of high-profile crimes, especially against women and children, there is the call from the public to crack down harder on sex offenders.

Mirra et al. (2011) reported that sexual crimes that occur in Pekanbaru for the period January to December 2009 for the category of the type of sexual violations in children are abuse in 50 cases (49\%), rape 46 cases (45\%), and sodomy 6 cases (6\%). The meaning of abuse here is touching or 
tarnishing that breaks the decency. Abuse against children is a violation of decency against a person who is considered immature age, either violent or nonviolent.

Cok (2014) reported sexual harassment of children increases in Bogor. Every year the number of abuse cases handled by the Police is increasing. The majority of the victims are at the age of 3 years old to 16 years old and come from poor families. Official data released Bogor Police during 2013, the number of sexual harassment cases that they handle are 55 cases. There are 50 cases have been resolved in court, while the rest is being done. The victims are 33 girls under the age of 10 years old and one boy with the same relative age, under ten years old. Meanwhile, until April of 2014, there are 16 cases. Totally five new cases can be resolved. The total numbers of victims of these cases are 14 women and two men.

The data above gives the reasons of the importance of early sex education. The reasons of this are the rapid technology development and the spread of sexual crimes. Sex education from an early age is so important because the damage that occurs to the victims. Another reason that sex education is important because sexual desire that associated with himself. Although some people have argued that children do not know about the sex drive, in Freud's Theory of the human desire states children who suck their thumbs considered having a sexual meaning. Libido or sex desire does not only mean as a driver of sexual interest, but it is also interpreted as physical energy. The tendency of children play his genitals is not an early sexual desire, but as a fundamental physical pleasure that gives color their lives. As time goes by, puberty makes active the hormonal glands sexually, and it cause libido.

The importance of early sex education also due to the essential character of human formed in childhood. Psychoanalyst has proved the good and bad effect in the first year of the child's primary character growth. Education is one of development influences of various forms of sexual deviation in the next period. Early sex education is possible to straighten understanding and sexual behavior of children so that they are more positive in social life. Research of Katharine Davies (as cited in M. Roqib, 2012) reinforces the importance of sex education. The result of the study is $57 \%$ women who received early sex education can marry happily. Early sex education to children protects them from sexual abuse. It expects that knowledge and the right attitude towards sex organs in young age, they can protect themselves from inducements from adults who will do sexual harassment.

Achieving the goals or objectives in every activity requires a strategy, as well as sex education. The strategy is the detailed plan for one action in meeting the goals and specific objectives. Thus, sex education strategy is detailed plans about early sex education to achieve the purpose of this activity. Sex education is far different from the sex, but generally, the parents feel uncomfortable, and it is considered as taboo matters. Whereas sex in this content means the gender or sex organs that have the particular function as well as other organs that also has a specific function in the human body. The role of the sex organs is for reproduction and also the recreation with their orgasm.

According to some experts, there are no definite restrictions on sex education. Sex education can be started when children start asking about the sex organs. The answer is given according to how far their curiosity and age of the children. Usually, a child asks for things like where his/her younger brother/sister comes out. In this case, parents need to answer wisely so that the child does not get confused with different answers when they ask the same question to others. Although there are no definite restrictions on sex education to children, there should be a strategy to convey this. Submission must be adapted to the purpose, the level of depth of the material, the children's age, the level of knowledge and maturity of the children, and media used in its delivery. When linked with the local culture, the explanation should not clash with the local tradition of positive, moral, and religious teachings.

In Javanese culture, sex education starts from social relationships in adolescence that are closely related to the achievement process of biological maturity level. The issue of sex is never 
discussed because it is still considered as taboo matters. They talk about it through the symbols to smooth its packaging. According to the Javanese view, sexual intercourse is something sublime, sacred, and has a function to maintain harmony and human survival. While in education, children can be given sex education since he/she asks about sex. It can be their questions are not spoken in words, so that parents and educators must capture the children's expression. According to Said Muhammad Mursi (2003), sex education can be started in early age because it is not only about the mere question and answer. Sex education also includes a case in point, habituation good morals, respect for the members of the body, instilling a sense of shame when genitalia visible to others or embarrassed to see the nakedness of others. Sex education for children needs to be taught from an early age, for example separating the bed between the girls and boys at the age of 10 years old, teaching them to ask for permission when entering his parents' bedroom.

However, Syarifuddin (2007) classifies sex education according to the phase of children development, namely: (1) First is Tamyiz (pre-puberty). This phase is between the age of 7 to 10 years old. At this stage, it is taught to recognize the self-identity is closely related to their biological organs as well as the differences between men and women. Children are given lessons such as asking permission and looking at something when it will enter their parents' bedroom. (2) Second is Murahaqah (puberty). This phase is at the age of 10 to 14 years old. At this stage, children should be given an explanation of the biological function scientifically, limit genitalia, decency, morality in society and dignity. At this stage, children should be kept away from the variety of sexual stimuli, such as cinemas, pornographic books, books that show inappropriate content and others. (3) Third is Bulugh (Adolescences Age). This phase is at the age of 14 to 16 years old. This phase is the most critical and important one because the instinct of curiosity in children is increasing along with increasingly the maturity of thinking. At this stage, children are ready to get married that marked with the functioning of the reproductive organs. Parents can give the ethics of sexual relationships to their children. (4) The fourth is during youth, after a period adolescent. At this time, children are given the lesson on ethics of isti'faaf (self-preservation), if it has not been able to get marriage.

According to Clara Kriswanto (as cited in Novita, 2007) sex education by age as follows: (1) At age 0 until five years old, parents help children to feel comfortable with their body. Giving touches and hugs to the children, so that they feel the love of her parents sincerely. Children must understand the difference between what can do and cannot do in public. For example, when the children finish showering, they should wear clothes in the bathroom or the bedroom. Parents should not allow the children are running naked after a bath. Children should know that there are personal things of their body that not everyone can touch or see it. They have to understand the differences between male and female body anatomy. The simple example to describe it by showing the process of the body, such as pregnancy and childbirth. In showing all of this, the parents should see the child's cognitive development. The important thing parents do not lie to children like saying that their sister or brother comes from the sky or taken by birds. Parents must try to put themselves as a child at that age and tell the things that they want to know. Or the parents can show the examples that occur in animals. Avoid feelings of shame and guilt for the shape and function of the body. Teach children to know the correct names of each part of the body and its functions. Tell vagina for the female genitals and penis to the male genitalia than say a bird or another. Help children understand the concept of personal and teach them that talks about sex are private. Provide support and conducive atmosphere so those children want to ask about sex to their parents. (2) At age six until nine years old, parents must stay informed sexual problems to the children, even if they do not ask. Explain that each family has its values that are commendable, such as the value to keep themselves as female or male and how to appreciate the opposite of sex. Besides that, provide basic information about sexual problems. Tell the children the changes that will happen when they hit puberty. (3) At age ten until 12 years old, parents must give the understanding about puberty phenomenon before experience itself, such as menstruation for girls as well as a wet dream for the boys. Therefore, the children get a preparation of the changes that will happen to them. Besides that, parents must respect the privacy of the children and encourage them to open communication. It must emphasize to children that the sexual maturation process of each is 
different. Help the children to understand their own physical. Even they are already an adult cognitively and emotionally, but they are not yet mature for sex. The understanding that many ways to express love and affection without sex are a necessary. The discussion about contraception and its function for married couples to birth control is also an important thing. And at last, talk about emotional and sexual feelings to them. (4) At age 13 until 15 years old, parents must teach about family values and religion. Describe to the children that there are a variety of ways to express love and discuss the factors that should be considered before sex. (5) At age 16 until 18 years old, parents must encourage their children to make decisions and to provide more information on what the decision should be taken.

Giving explanation about the sex education at an early age (and in adolescence) have some advantages. The advantages are (1) Helping children to know biological topics such as growth, puberty, and pregnancy. (2) Preventing children from violence. (3) Reducing guilt, shame, and anxiety due to the sex action. (4) Preventing underage pregnancy. (5) Preventing young teenagers do sexual intercourse (sexual intercourse). (6) Reducing cases of infection or disease because of sex. (7) Helping young people are asking about the roles of men and women in society.

Parents are responsible for the education of their children including sex education. Since childhood, children spend time with their parents, so that most parents know the character of their children. The closeness of their relationship makes the parents have the sensitivity to what is happening with their children. If there are any improper changes, parents will notice it quickly. The parents can detect the abuse against children earlier. Furthermore, sex education is also provided through the guidance that was held at the school. There are also sex educations programs are held in worship places. Sex education cannot be separated from moral education and faith aspects. So that, parents must give that knowledge to the children to keep away themselves from sexual harassment.

\section{CONCLUSIONS}

Children are the future generation that their existence needs to be maintained. By seeing so many cases of sexual abuse against children and the dangerous impacts of it, nation's generation will experience the destruction. There should be action from the government in this case, and the victims must get defense. Their parents must give children the early sex education to avoid them from its crime. Sex education must be accompanied by moral and faith education so that children are expected can prevent this crime in their social life.

\section{REFERENCES}

Abdullah, S. (2014). Terungkap mantan Guru Jis Ternyata Pernah Perkosa 90 Bocah. Retrieved June $7^{\text {th }} 2014$ from http://www.republika.co.id/berita/nasional/hukum/14/04/23

Asyhad, H. (2014). Sepertiga Anak sekolah Tidak Mendapat Pendidikan Seks. Retrieved November $22^{\text {nd }} 2015$ from http://nationalgeographic.co.id/berita/2014/01/sepertiga-anak-sekolah-takmendapat-pendidikan-seks

Cok. (2014). Kasus Pelecehan Seksual Kepada Anak Meningkat. Retrieved June $7^{\text {th }} 2014$ from http://www.jpnn.com/read/2014/05/12/233857/

Darmadi, H. (1977). Dasar Konsep Pendidikan Moral. Bandung: Alfabeta. 
Flanagan, J. (2011). South African men rape babies as 'cure' for Aids. Retrieved June $7^{\text {th }} 2014$ from http://www.telegraph.co.uk/news/worldnews/africaandindianocean/southafrica/1362134/Sou th-African-men-rape-babies-as-cure-for-Aids.html

Madani, Y. (2003). Pendidikan Seks untuk Anak dalam Islam Pustaka Zahra. Cetakan 2. Jakarta: Pustaka Zahra.

Midfilder, F. (2012). Pengertian Pendidikan. Retrieved January $1^{\text {st }} 2016$ from http://pengertiandariahli.blogspot.co.id/2012/07/pengertian-pendidikan.html

Mirra, N. M., Harmaini., \& Deuce, B. P. (2011). Pemprofilan Kejahatan Sexual Terhadap Anak di Pekan Baru. Jurnal Psikologi. Retrieved May $25^{\text {th }} 2014$ from http://fpsi.uinsuska.ac.id/sites/default/files/perpustakaan/download/177PEMPROFILAN\%20 PELAKU-189.pdf

Mursi, S. M. (2003). Seni Mendidik Anak (2 ${ }^{\text {nd }}$ Ed). Jakarta: Pustaka Al-Kautsar.

Novita, W. (2007). "Serba Serbi Anak" yang perlu diketahui seputar Anak dari kandungan hingga masa sekolah (tinjauan Psikologis dan Kedokteran). Jakarta: PT Elex Media Komputindo.

Psychologymania. (2013). Pengertian Pendidikan Seks. Retrieved June $7^{\text {th }} 2014$ from http://www.psychologymania.com/2013/02/ html

Rasyid, HMHA. (2014). Tiap 25 Menit Kejahatan Sex Terjadi di Korsel. Retrieved June $7^{\text {th }} 2014$ from http://blognyarahmat.blogspot.co.id/2013/09/di-korsel-kejahatan-seks-terjadi-tiap.html

Riz. (2014). Kejadian Luar Biasa Kasus Paedofil Emon-114 Anak Jadi Korban. Retrieved June $7^{\text {th }}$ 2014 from http://news.liputan6.com/read/2048164/

Roqib, M. (2009). Ilmu Pendidikan Islam: Pengembangan Pendidikan Integratif di Sekolah, Keluarga, dan Masyarakat. Cetakan 1. Yogyakarta: LKISYogyakarta

Roqib, M. (2008). Pendidikan Seks Pendidikan Seks pada Anak Usia Dini. Jurnal Alternatip Pendidikan INSANIA, 13(2), 271-286. Retrieved May 25 ${ }^{\text {th }} 2014$ from http://insaniaku.files.wordpress.com

Setiawan, A. (2014). Akhir 3 Kasus Pelecehan Seksual di Sekolah. Retrieved June $7^{\text {th }} 2014$ from http://www.tempo.co/read/news/2014/04/15/064570761/

Soemanto, W. (2006). Psikologi Pendidikan: Landasan Kerja Pemimpin Pendidikan. Jakarta: Rineka Cipta

Supriadi, D. (2001). Reformasi Pendidikan dalam Konteks Otonomi Daerah. Yogyakarta: Adicita Karya Nusa

Suraji, \& Sofia, R. (2008). Pendidikan Seks Bagi Anak. Yogyakarta: Pustaka Fahima

Syarifuddin, N. (2007). Seminar Perempuan dengan Tema "Seksologi: Antara Perlu dan Tabu". Retrieved May 25 2014 from http://jktcry.wordpress.com/2011/12/08/pendidikan-seksuntuk-keluarga-anak-dan-remaja/

Tanjung, C. A. (2014). Lagi, Anak dibawah Umur Jadi Korban Kejahatan Seksual di Riau. Retrieved June 7th 2014 from http://news.detik.com/read/2014/05/08/165233/2577407/10 
Tarigan, A. E. (2015). Pengertian Pendidikan Seks. Retrieved January $1^{\text {st }} 2016$ from http://tariganae.blogspot.co.id/2015/12/pengertian-pendidikan-seks.html

Ulum, M. M. (2014). Definition and Purpose of Education. Retrieved January $1^{\text {st }} 2016$ from http://chantryintelex.blogspot.co.id/2014/08/definition-and-purpose-of-education.html

Yus. (2014). 20 Anak Jadi Korban Pelecehan Seksual Guru di Samarinda. Retrieved June $7^{\text {th }} 2014$ from http://news.liputan6.com/read/2048876 